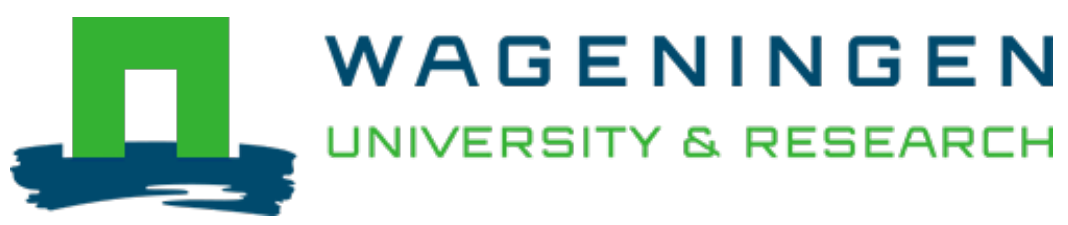

\author{
Characteristics of some traditional Vietnamese starch-based rice wine \\ fermentation starters (men) \\ Food Science and Technology = Lebensmittel-Wissenschaft und Technologie \\ Dung, N.T.P.; Rombouts, F.M.; Nout, M.J.R. \\ https://doi.org/10.1016/j.lwt.2005.08.004
}

This publication is made publicly available in the institutional repository of Wageningen University and Research, under the terms of article $25 \mathrm{fa}$ of the Dutch Copyright Act, also known as the Amendment Taverne. This has been done with explicit consent by the author.

Article 25 fa states that the author of a short scientific work funded either wholly or partially by Dutch public funds is entitled to make that work publicly available for no consideration following a reasonable period of time after the work was first published, provided that clear reference is made to the source of the first publication of the work.

This publication is distributed under The Association of Universities in the Netherlands (VSNU) 'Article $25 \mathrm{fa}$ implementation' project. In this project research outputs of researchers employed by Dutch Universities that comply with the legal requirements of Article $25 \mathrm{fa}$ of the Dutch Copyright Act are distributed online and free of cost or other barriers in institutional repositories. Research outputs are distributed six months after their first online publication in the original published version and with proper attribution to the source of the original publication.

You are permitted to download and use the publication for personal purposes. All rights remain with the author(s) and / or copyright owner(s) of this work. Any use of the publication or parts of it other than authorised under article $25 \mathrm{fa}$ of the Dutch Copyright act is prohibited. Wageningen University \& Research and the author(s) of this publication shall not be held responsible or liable for any damages resulting from your (re)use of this publication.

For questions regarding the public availability of this publication please contact openscience.library@wur.nl 


\title{
Characteristics of some traditional Vietnamese starch-based rice wine fermentation starters (men)
}

\author{
N.T.P. Dung ${ }^{\mathrm{a}}$, F.M. Rombouts ${ }^{\mathrm{b}}$, M.J.R. Nout ${ }^{\mathrm{b}, *}$ \\ ${ }^{a}$ Biotechnology Research and Development Institute, Can Tho University, Can Tho City, Vietnam \\ ${ }^{\mathrm{b}}$ Laboratory of Food Microbiology, Department of Agrotechnology and Food Sciences, P.O. Box 8129, 6700 EV Wageningen University, The Netherlands
}

Received 13 January 2005; received in revised form 4 August 2005; accepted 17 August 2005

\begin{abstract}
In the Mekong Delta region of South-Vietnam, wine from purple glutinous rice is particularly interesting because of its sherry-like taste and flavour and its attractive brown-red colour. It is manufactured at home or by small cottage industries, using traditional solidstate starters (Men). With the objective of improving the knowledge about the functionality of traditional Men, this study deals with the properties and composition of 29 samples of Vietnamese commercial rice wine starters. We selected 6 rice wine starters for their superior ability to liquefy cooked rice, high ethanol accumulation, and production of attractive flavour and colour in the resulting wine. Ethanol contents reached $12 \mathrm{~g} / 100 \mathrm{ml}$, a sweet alcoholic fragrance was noticed and the wine colour varied from red to lightly brown. Total mould, yeast and bacteria counts in Men were 3.4-6.0, 5.8-7.2 and 2.6-6.2 log CFU/g of dry weight sample, respectively. A total of 119 microbial strains, comprising 53 moulds, 51 yeasts and 15 bacteria, was isolated. Mould isolates with excellent functionality were identified as Amylomyces rouxii, Amylomyces aff. rouxii (an atypical form of A. rouxii), Rhizopus oligosporus and Rhizopus oryzae. Yeast isolates with excellent fermentation properties were all identified as Saccharomyces cerevisiae; other, less functional isolates were identified as Candida glabrata and Pichia anomala.
\end{abstract}

(C) 2005 Swiss Society of Food Science and Technology. Published by Elsevier Ltd. All rights reserved.

Keywords: Fermentation starter; Men; Moulds; Yeasts

\section{Introduction}

Like other traditional fermented alcoholic beverages in other East-Asian countries (Basuki et al., 1996; Hesseltine, 1983; Nout \& Aidoo, 2002), rice wines are popular in Vietnam. The manufacture of rice wine can be characterized as the conversion of rice (Oryza sativa L.) by physical, microbiological and biochemical operations including steaming, inoculation with starter, mashing and fermentation. The alcohol content of Vietnamese rice wines varies and can reach up to $15 \mathrm{ml} / 100 \mathrm{ml}$ (about $12 \mathrm{~g} / 100 \mathrm{ml}$ ); by distillation, products with approximately $50 \mathrm{ml} / 100 \mathrm{ml}$ (about $40 \mathrm{~g} / 100 \mathrm{ml}$ ) alcohol can be obtained.

In Vietnam, the production of rice wine is a source of income for farmer families in rural areas. In Vietnamese,

\footnotetext{
${ }^{*}$ Corresponding author. Tel.: + 31317482834 ; fax: + 31317484978 .

E-mail address: rob.nout@wur.nl (M.J.R. Nout).
}

Ruou means wine. In the north and south, we can find Ruou De or Ruou Nep: these are fermented from rice or glutinous rice, respectively, followed by distillation. In mountainous districts, such as Da Lat, Buon Me Thuot, and Dac Lac, an ethnic minority (Thuong people) produce Ruou Can that is fermented from rice, maize or cassava, with or without distillation.

In particular in the Mekong Delta of the south, Ruou Nep Than (purple glutinous rice wine) is made from purple glutinous rice without further distillation. It is commercialized in two qualities: crude cloudy wine containing sediment, and clear filtered wine. Its manufacture follows a traditional fermentation process in which powdered starch-based starter is mixed with steamed gelatinized purple glutinous rice, which is then incubated under ambient conditions. After an initial period of uncontrolled aerobic fungal solid-state fermentation, the now moulded mass is mixed with water, and is allowed to undergo 
submerged alcoholic fermentation. After filtration, the final product is a clear purple liquid containing a mixture of residual glucose, accumulated ethanol and other soluble matter.

Mostly the alcohol content in the final product is approximately $\quad 7-10 \mathrm{ml} / 100 \mathrm{ml}$ (about 6-8 g/100 ml), which would be insufficient to preserve the wine. Enrichment with (distilled) rice wine alcohol is often practiced to strengthen the liquor and enhance its shelf-life. The yield, flavour and overall acceptability obtained with these uncontrolled fermentation operations vary to such an extent that this is considered as a problem by local producers.

Local winemakers are aware that the choice of starter tablets, called Men in Vietnamese, influences the yield and quality of wine. Three major microbial groups namely moulds, yeasts and bacteria (Hesseltine, Rogers, \& Winarno, 1988; Lim, 1991; Steinkraus, 1989) are encountered in traditional rice wine starters. It is generally held that moulds are the major producers of amylases that degrade starch into fermentable sugars, and that the yeasts convert the sugars to alcohol. Bacteria, mainly lactic acid bacteria (LAB), most likely occur as opportunistic contaminants. However, little is known about the comparative functionality of fungal species in these starters. Our research interest focuses on the role of individual moulds and yeasts during starch degradation and alcoholic fermentation, in a view to develop superior defined mixed starters at a later stage.

Three main kinds of Vietnamese traditional starters can be distinguished (Luong, 1998; Phuc, 1998): (a) without and (b) supplemented with oriental medicinal herbs and (c) starters supplemented with leaves containing aromatic essential oils. In the Mekong Delta region, starters of type (b) predominate. The types and quantities of herbs used may vary according to the different local producers; however, some commonly used oriental herbs in starter manufacture are: "Nhuc Dau Khau" (Mace: Myristica fragrans Houtt), "Cam Thao" (Licorice root: Glycyrrhiza uralensis Fish), "Te Tan" (Ginger: Asarum sieboldii Miq.), "Thao Qua" (Cardamom: Amomum tsao-ko Crev. et Lem.), "Tieu hoi" (Fennel: Foeniculum vulgare Miller), and "Dinh Huong" (Clove: Syzygium aromaticum L.). The latter supplements are used to produce fragrance and are believed to suppress the growth of undesired microorganisms in the final products.

Taking into consideration the situation of Vietnam in which each locality has its own way of producing starch-based rice wine starter, depending on available ingredients and preferences, the objective of this study is to pave the way for upgrading the traditional starter tablet technology for winemaking. This paper presents the functionality of a number of Vietnamese rice-wine starters in terms of their alcohol production, with rice saccharification and alcoholic fermentation stages as crucial assessment criteria, and identifies representative functional moulds and yeasts.

\section{Materials and methods}

\subsection{Sample collection}

Twenty-nine samples of dry commercial traditional rice wine starters were obtained from small-scale factories and markets in different provinces. Sampling was focused particularly on the leading producers in the Mekong Delta region. All starters were classified as type (b) (see Section 1). The starters were subjected to microbiological analysis immediately after collection. Samples were stored at $4{ }^{\circ} \mathrm{C}$ prior to screening for their functional properties.

\subsection{Fermentation test}

We adapted the traditional process for making rice wine for use at laboratory scale, as follows: (step \#1) fifty grams of purple glutinous rice and $60 \mathrm{ml}$ of distilled water in a 500-ml conical flask covered by a cotton plug were soaked (\#2) for $4 \mathrm{~h}$ at room temperature $\left(25^{\circ} \mathrm{C}\right)$. After soaking they were steamed (\#3) in an autoclave for $1 \mathrm{~h}$ at $100^{\circ} \mathrm{C}$. The gelatinized rice paste was cooled to $35-40{ }^{\circ} \mathrm{C}(\# 4)$, then inoculated and mixed well with $2 \mathrm{~g}$ of powdered starter to be tested (\#5). After solid-state aerobic fungal fermentation during 3 days at $30^{\circ} \mathrm{C}(\# 6), 70 \mathrm{ml}$ of sterile water was added (\#7) to the moulded mass to allow for submerged alcoholic fermentation for 7 days at $30^{\circ} \mathrm{C}$ in the same flask, closed with a water lock (\#8). All of the fermented rice mass was homogenized (\#9) using a Stomacher Labblender (Seward 400, Emergo, England) and clear liquid was harvested after centrifugation (\#10) at $3660 \mathrm{rpm}$ for 20 min (Mistral 3000i; rotor windshield 43124-708 BS 4402, Leicester, United Kingdom); clear liquid (supernatant) was decanted (\#11). Each sample was tested in triplicate.

\subsection{Analytical methods}

Numbers in brackets refer to the manufacturing stages mentioned in "Fermentation test" above. The $\mathrm{pH}$ after soaking (\#2), after solid-state fermentation (\#6) and after submerged fermentation (\#8) was measured by digital $\mathrm{pH}$ metre (WTW pH 525). Flavour after (\#6) and after (\#8) was assessed subjectively by a small expert panel. Colour of clear final liquid was measured by Colorimeter Tricolor LFM3 (Dr. Lange), in which the $L^{*}, a^{*}, b^{*}$ system (DIN 6174, CIE-LAB standardized in 1976) was used. Glucose and ethanol after solid-state fermentation (\#6) and after alcoholic fermentation (\#8) were analysed by HPLC Organic Acid Analysis Column-Aminex HPX-87 H Ion Exclusion Column $300 \mathrm{~mm} \times 7.8 \mathrm{~mm}(\mathrm{BIO}-\mathrm{RAD})$.

\subsection{Microbiological analysis}

For microbiological analysis, a sample of $1 \mathrm{~g}$ of each selected starter was transferred to a stomacher bag and homogenized with $99 \mathrm{ml}$ sterile saline $(\mathrm{NaCl} 0.85 \mathrm{~g} / 100 \mathrm{ml})$ in a Stomacher Lab-blender 400 for $1 \mathrm{~min}$ at high speed, 
and appropriate serial dilutions were made in the same diluent. In total, 1-ml portions of the appropriately diluted suspension were mixed with molten $\left(45^{\circ} \mathrm{C}\right)$ medium and made into pour-plates.

Moulds were enumerated on Czapek-Dox Agar rendered selective for fungi by addition of oxytetracycline. The medium contained $(\mathrm{g} / \mathrm{l})$ sodium nitrate 2, potassium chloride 0.5 , magnesium glycerophosphate 0.5 , ferrous sulphate 0.01 , potassium sulphate 0.35 , sucrose 30 , agar 20 . To $900 \mathrm{ml}$ of basal medium, $100 \mathrm{ml}$ containing $100 \mathrm{mg}$ sterile filtered solution of oxytetracycline was added. Oxytetracycline Glucose Yeast Extract Agar was used for yeast count. The ingredients $(\mathrm{g} / \mathrm{l})$ were yeast extract 5 , glucose 20, agar 12. Oxytetracycline was added to this medium as above.

MRS medium was used to determine the LAB count. It contains $(\mathrm{g} / \mathrm{l})$ peptone from casein 10 , meat extract 8 , yeast extract $4, \mathrm{D}(+)$ glucose 20, di-potassium hydrogen phosphate 2, Tween-80 1, di-ammonium hydrogen citrate 2 , sodium acetate 5 , magnesium sulfate 0.2 , manganese sulfate 0.04 , agar technical 12 . To $1-1$ medium $2 \mathrm{~g}$ natamycin dissolved in $40 \mathrm{ml}$ of sterile water was added to prevent fungal growth.

All plates were incubated at $30^{\circ} \mathrm{C}$ for $2-4$ days. The colonies that appeared after incubation were counted and calculated as colony forming units (CFU) per gram of dry weight sample.

\subsection{Isolation and purification of microorganisms}

In order to select for the most active strains in the various starters we isolated from fermentations initiated by these starters, instead of sampling the starters directly. For moulds: after completing the solid-state fermentation step (\#6) of the fermentation test (mentioned above) a piece of moulded rice covered with mycelium was transferred and spread onto a plate containing sterile Czapek-Dox Agar supplemented with oxytetracycline, incubated at $30^{\circ} \mathrm{C}$ for 3 days and resulting colonies were purified on Czapek-Dox agar.

For yeasts: after completing the alcoholic fermentation step (\#8) appropriate dilutions were made into pouring plates with Oxytetracyclin Glucose Yeast Extract Agar which was incubated at $30^{\circ} \mathrm{C}$ for 1 or 2 days. Colonies were purified on Glucose Yeast Extract agar.

For LAB: during step (\#6) of the fermentation test, $1 \mathrm{ml}$ of liquid released by the moulded mass was diluted and pour-plated into MRS supplemented with natamycin, incubated at $30^{\circ} \mathrm{C}$ for 4 days, and colonies were isolated and purified on MRS agar.

\subsection{Identification of moulds and yeasts}

Mould isolates were identified based on morphological examination and cultural properties according to established taxonomic keys and descriptions (Hesseltine, 1991; Samson \& Hoekstra, 2002).
Yeasts were identified on the basis of their cell morphology, biochemical and physiological growth properties (Rohm, Lechner, \& Lehner, 1990; Middelhoven, 2000; Yarrow, 1998), as well as on internal transcribed spacer (ITS) sequences (Han, Kuijpers, Thanh, \& Nout, 2004; Kurtzman, Boekhout, Robert, Fell, \& Deak, 2003). Classification followed the taxonomic keys, references and BioloMICS software (http://www.cbs.knaw.nl) (Barnett, Payne, \& Yarrow, 2000; Kurtzman \& Fell, 1998; Smith, Yarrow, \& Robert, 2002).

\subsection{Statistical analysis}

Experimental data were statistically analysed using Statgraphics Plus Version 5, Manugistics, Inc.

\section{Results and discussion}

\subsection{Initial testing of starters}

All tested starters converted purple glutinous rice into wine. After the first 3 days of fungal solid-state fermentation under aerobic conditions, liquefaction and saccharification were clearly noticeable: liquid of high glucose content was released by the moulded mass which showed abundant mycelial growth in certain cases. During the next stage of 7-day incubation under exclusion of air, the alcoholic fermentation took place as observed by gas formation.

Table 1 shows the mean values of three replications of liquefaction, $\mathrm{pH}$, glucose, ethanol and colour measurements. The ethanol content obtained after alcoholic fermentation is an important criterion for functionality. Statistical analysis revealed significantly $(P<0.05)$ different alcohol levels between starters tested.

Differences of liquefaction patterns were also observed. There was a positive correlation between the extent of liquefaction and the production of ethanol. For starters 2, $6,15,20,23$ and 29 the results show that stronger liquefaction during the aerobic solid-state fermentation is associated with higher accumulated ethanol levels in the final product. This can be explained by strong activities of both moulds and yeasts in the microflora of the corresponding starters. However, high levels of reducing sugars were not necessarily completely converted into ethanol; for instance, in starters 9, 11, 14, 17, 18 and 27 high glucose, but low ethanol contents were obtained at the end of the alcoholic fermentation suggesting that the yeasts in these starters have limited abilities to accumulate ethanol.

The initial $\mathrm{pH}$ of soaked purple glutinous rice decreased from 5.6 to the range of 3.8-4.6 after the first 3 days of incubation and then remained quite stable around 3.5-4.3 until the end of the fermentation.

On visual inspection, the colour of the final products was described as red to lightly brown. The colour was also measured by Colorimeter using the $L^{*} a^{*} b^{*}$-system. The 
Table 1

Performance of Vietnamese traditional rice wine starters

\begin{tabular}{|c|c|c|c|c|c|c|c|c|c|c|}
\hline \multirow[t]{2}{*}{ Starter } & \multirow{2}{*}{$\begin{array}{l}\text { Liquefaction of } \\
\text { steamed rice } \\
\text { After mould } \\
\text { fermentation }\end{array}$} & \multicolumn{2}{|l|}{$\mathrm{pH}$} & \multicolumn{2}{|c|}{ Glucose $(\mathrm{g} / 100 \mathrm{ml})$} & \multicolumn{2}{|c|}{ Ethanol $(\mathrm{g} / 100 \mathrm{ml})$} & \multicolumn{3}{|c|}{$\begin{array}{l}\text { Colour measurement }{ }^{\mathrm{b}} \text { after } \\
\text { wine filtration }\end{array}$} \\
\hline & & $\begin{array}{l}\text { After mould } \\
\text { fermentation }\end{array}$ & $\begin{array}{l}\text { After alcoholic } \\
\text { fermentation }\end{array}$ & $\begin{array}{l}\text { After mould } \\
\text { fermentation }\end{array}$ & $\begin{array}{l}\text { After alcoholic } \\
\text { fermentation }\end{array}$ & $\begin{array}{l}\text { After mould } \\
\text { fermentation }\end{array}$ & $\begin{array}{l}\text { After alcoholic } \\
\text { fermentation }\end{array}$ & $\mathrm{L}$ & a & $\mathrm{b}$ \\
\hline 1 & ++ & 3.8 & 3.6 & 19.3 & 0.6 & 5.3 & $10.2 \operatorname{cdef}^{c}$ & 50.7 & 27.5 & 17.1 \\
\hline 2 & +++ & 4.1 & $3.9 \mathrm{~b}$ & $12.9 \mathrm{~b}$ & 0.1 & $8.2 \mathrm{c}$ & $11.0 \mathrm{~b}$ & 43.8 & 30.6 & 20.4 \\
\hline 3 & + & 4.6 & 3.6 & 20.2 & 0.3 & 5.0 & 9.6 hik & 45.8 & 29.7 & 20.8 \\
\hline 6 & +++ & 4.6 & $4.2 \mathrm{a}$ & $21.7 \mathrm{a}$ & 0.1 & $5.6 \mathrm{e}$ & $11.2 \mathrm{~b}$ & 42.5 & 33.1 & 22.2 \\
\hline 7 & + & 4.4 & 3.7 & 17.5 & 1.2 & 4.8 & $10.5 \mathrm{c}$ & 51.5 & 21.2 & 21.7 \\
\hline 8 & ++ & 3.9 & 3.7 & 14.4 & 1.1 & 6.6 & 9.9 efghi & 49.1 & 26.4 & 20.7 \\
\hline 9 & + & 4.4 & 3.5 & 24.5 & 0.9 & 4.2 & $9.5 \mathrm{ik}$ & 48.4 & 29.6 & 19.1 \\
\hline 10 & + & 4.4 & 3.5 & 24.1 & 0.7 & 4.5 & $10.0 \mathrm{defg}$ & 46.4 & 30.6 & 19.7 \\
\hline 11 & ++ & 4.0 & 3.5 & 24.2 & 0.6 & 4.6 & 9.6 hik & 49.4 & 26.8 & 18.8 \\
\hline 16 & ++ & 4.5 & 4.1 & 18.4 & 0.2 & 7.6 & $10.3 \mathrm{~cd}$ & 47.7 & 26.1 & 21.6 \\
\hline 17 & + & 4.1 & 3.4 & 20.1 & 1.1 & 4.5 & 9.6 hik & 47.2 & 30.4 & 18.9 \\
\hline 18 & + & 4.2 & 3.7 & 24.3 & 2.3 & 4.9 & 8.81 & 49.1 & 27.1 & 20.5 \\
\hline 19 & ++ & 4.6 & 4.1 & 18.1 & 0.4 & 5.8 & $10.3 \mathrm{~cd}$ & 48.7 & 24.9 & 22.9 \\
\hline 20 & +++ & 4.4 & $4.3 \mathrm{a}$ & $12.9 \mathrm{~b}$ & 0 & $9.3 \mathrm{~b}$ & $11.7 \mathrm{a}$ & 46.4 & 29.8 & 22.2 \\
\hline 21 & +++ & 4.6 & 4.2 & 16.2 & 0.4 & 6.9 & $10.1 \mathrm{cdefg}$ & 50.8 & 22.2 & 22.1 \\
\hline 22 & +++ & 4.6 & 4.1 & 12.9 & 0.6 & 7.2 & $10.2 \mathrm{cde}$ & 48.6 & 26.2 & 20.9 \\
\hline 23 & +++ & 4.4 & $4.3 \mathrm{a}$ & $9.5 \mathrm{~d}$ & 0.1 & 10.1 a & $12.0 \mathrm{a}$ & 44.6 & 29.5 & 19.7 \\
\hline 24 & + & 4.6 & 4.1 & 22.4 & 0.4 & 5.8 & $10.5 \mathrm{c}$ & 49.1 & 25.1 & 22.1 \\
\hline 25 & ++ & 4.6 & 4.4 & 20.9 & 0.5 & 6.0 & $10.3 \mathrm{~cd}$ & 54.9 & 18.8 & 21.0 \\
\hline 26 & ++ & 4.5 & 4.3 & 13.5 & 0.6 & 7.5 & $10.2 \mathrm{cdef}$ & 54.8 & 20.0 & 19.9 \\
\hline 27 & + & 4.6 & 3.6 & 20.6 & 1.1 & 5.8 & $9.4 \mathrm{k}$ & 46.8 & 27.7 & 21.6 \\
\hline
\end{tabular}

${ }^{\text {a }}$ Levels of liquefaction ranging from + (little) to +++ (very much); starters bold are those selected for further study.

${ }^{\mathrm{b}}$ Colour of clear liquid was measured by Colorimeter Tricolor LFM3, in which the L*, $\mathrm{a}^{*}, \mathrm{~b}^{*}$ system (DIN 6174, CIE-LAB standardized in 1976) was used $(\mathrm{L}=$ luminosity, $\mathrm{a}=$ red component, $\mathrm{b}=$ blue component $)$.

${ }^{\mathrm{c}}$ Means with different subscripts are statistically significant at the $95 \%$ confidence level.

results show that the choice of starters did not strongly influence the perceived and measured colour of the wine.

The flavour of the fermenting rice was recorded after 3 days and at the end of the fermentation. After 3 days, a sweet fragrance was dominant in all treatments except with starters 9 and 28 which caused a slightly sour flavour, whereas slight alcoholic flavour was noticed with starters 2 , 12, 20, 23 and 29. The final products had a strong alcohol flavour in all cases, and in starters 1, 2, 3, 20 and 29, sweet odours still remained detectable.

During the fermentation process, glucose contents were high after the first 3 days, but were exhausted in most cases at the end of the fermentation. Concomitantly, ethanol levels increased, confirming expectations that starch will first be converted into sugars and these subsequently into alcohol. With starters 2, 12, 20, 23 and 29, glucose contents were rather low after mould fermentation but nevertheless they were accompanied by significant levels of ethanol. We assume that in these cases, the yeasts had already started to convert glucose as soon as it was produced and continued exhausting it towards the end of the fermentation. In contrast, the yeasts in starters $9,10,11,14$ and 18 only weakly fermented glucose that had been formed at high levels, resulting in low ethanol levels and significant residual sugar in the final product. In the case of starters $2,6,15,20,23$ and 29 we observed a complete fermentation, i.e. exhaustion of glucose. In all treatments, ethanol was detectable already after the first few days of the process, indicating that the production of rice wine using a starch-based starter is indeed the result of mixed and simultaneous fermentations. We also observed that all starters contained yeasts that were able to grow under aerobic conditions; however, the significant increase of ethanol levels later during the process shows that fermentation by the yeasts is favoured by anaerobic conditions. 
These data show a considerable variation of starter functionality. Some starters $(2,6,15,20,23$ and 29) were considered of interest for further investigation because of their capacity for rice liquefaction, their significantly higher ethanol accumulation, as well as the flavour and the colour of their wines.

\subsection{Microflora composition}

Predominant groups of microorganisms were enumerated in the six selected starters and reported as $\log \mathrm{CFU} / \mathrm{g}$ of dry weight sample as shown in Table 2. Although it is known that mould counts represent their extent of sporulation rather than their viable biomass, in this case the use of CFU counts will be appropriate as the spore germination activity is essential for starter performance. Yeasts were present in the highest numbers (up to $7.2 \mathrm{log}$ $\mathrm{CFU} / \mathrm{g}$ starter). In general, LAB were present at relatively low levels compared to yeasts and moulds. In relation with

Table 2

Total mould, yeast and lactic acid bacteria (LAB) counts (log CFU/g dry weight) of selected fermentation starters

\begin{tabular}{|c|c|c|c|c|c|c|c|c|c|}
\hline \multirow[t]{2}{*}{ Starter } & \multicolumn{3}{|c|}{ Moulds } & \multicolumn{3}{|c|}{ Yeasts } & \multicolumn{3}{|c|}{ LAB } \\
\hline & $\mathrm{a}^{\mathrm{a}}$ & $\mathrm{b}$ & $\begin{array}{l}\text { Mean } \\
\text { values }\end{array}$ & $\mathrm{a}$ & $\mathrm{b}$ & $\begin{array}{l}\text { Mean } \\
\text { values }\end{array}$ & $\mathrm{a}$ & $\mathrm{b}$ & $\begin{array}{l}\text { Mean } \\
\text { values }\end{array}$ \\
\hline 2 & 5.8 & 6.2 & $6.0 \mathrm{a}^{\mathrm{b}}$ & 7.4 & 6.8 & $7.1 \mathrm{a}$ & 5.8 & 6.6 & $6.2 \mathrm{a}$ \\
\hline 6 & 5.0 & 3.6 & $4.3 \mathrm{~d}$ & 7.0 & 6.6 & $6.8 \mathrm{bc}$ & 4.2 & 5.2 & $4.7 \mathrm{~b}$ \\
\hline 15 & 3.7 & 3.1 & $3.4 \mathrm{e}$ & 6.1 & 5.5 & $5.8 \mathrm{~d}$ & 2.9 & 2.3 & $2.6 \mathrm{f}$ \\
\hline 20 & 5.5 & 4.7 & $5.1 \mathrm{~b}$ & 7.1 & 7.3 & $7.2 \mathrm{a}$ & 4.8 & 4.0 & $4.4 \mathrm{c}$ \\
\hline 23 & 5.1 & 4.1 & $4.6 \mathrm{c}$ & 6.5 & 7.3 & $6.9 \mathrm{~b}$ & 4.1 & 3.9 & $4.0 \mathrm{~d}$ \\
\hline 29 & 4.8 & 4.2 & $4.5 \mathrm{c}$ & 7.0 & 6.4 & $6.7 \mathrm{c}$ & 3.6 & 3.0 & $3.3 \mathrm{e}$ \\
\hline
\end{tabular}

${ }^{\mathrm{a}} \mathrm{a}$ and $\mathrm{b}$ are duplicates.

${ }^{\mathrm{b}}$ Means with different subscripts are statistically significant at the $95 \%$ confidence level. the performance of selected starters (Table 1), low $\mathrm{pH}$ can have resulted from the presence of higher numbers of $\mathrm{LAB}$ such as in starter 2; on the other hand, yeasts are also able to reduce the $\mathrm{pH}$ by their efflux of protons. In starters 2 , 20, 23 and 29, glucose contents after mould fermentation were significantly lower in comparison with results in starters 6 and 15, and vice versa ethanol contents in the former starters were significantly higher. This may have been caused by a rapid conversion of glucose by the yeasts as soon as it was formed from starch. This would also partly explain the high yeast counts in starters. However, starter 6 is an exception, indicating that not only cell numbers but rather their species determine the functionality of the starters.

\subsection{Identification of selected moulds and yeasts}

A total of 119 strains, comprising 53 moulds, 51 yeasts and 15 bacteria, was isolated. This investigation focussed on improving performance, so the isolated fungi were subjected to a screening program of which the main outcomes are summarized in Table 3 . Three main groups of moulds and yeasts were distinguished according to their starch degradation and ethanol production, respectively. Eight mould isolates expressing strong starch degrading ability that was evaluated by measuring diameters of clearing zones in rice-starch agar, were selected for further studies and identified as four species, namely Amylomyces rouxii, Amylomyces aff. rouxii (an atypical form of $A$. rouxii), Rhizopus oligosporus and Rhizopus oryzae. These species were also found earlier in amylolytic fermentation starters used in the production of alcoholic beverages in various Asian countries (Hesseltine et al., 1988; Nout \& Aidoo, 2002). All species belong to genera of the Zygomycetes, which are commonly found in foods; these are confined to the order Mucorales. The moulds in this

Table 3

Summary of main outcomes of mould and yeast screening for their functionality and the identification of representative isolates

\begin{tabular}{|c|c|c|c|c|c|c|}
\hline \multirow{2}{*}{$\begin{array}{l}\text { Group of } \\
\text { isolates }\end{array}$} & \multicolumn{2}{|c|}{ Starch degradation by moulds ${ }^{\mathrm{a}}$} & \multicolumn{2}{|c|}{ Fermentative capacity by yeasts ${ }^{\mathrm{b}}$} & \multicolumn{2}{|c|}{ Identification of representative isolates } \\
\hline & Number of isolates & $\begin{array}{l}\text { Diameter of } \\
\text { clearing zone }(\mathrm{cm})\end{array}$ & Number of isolates & $\begin{array}{l}\text { Alcohol content } \\
(\mathrm{g} / 100 \mathrm{ml})\end{array}$ & Moulds & Yeasts \\
\hline Group 1 & 8 & $7.1-9.0$ & 45 & $8.2-8.8$ & $\begin{array}{l}\text { Amylomyces rouxii ( } 3 \\
\text { strains); Amylomyces } \\
\text { aff. rouxii (1 strain); } \\
\text { Rhizopus oligosporus } \\
\text { (1 strain); Rhizopus } \\
\text { oryzae (3 strains) }\end{array}$ & $\begin{array}{l}\text { Saccharomyces } \\
\text { cerevisiae ( } 5 \\
\text { strains) }\end{array}$ \\
\hline Group 2 & 21 & $5.0-6.3$ & 5 & $5.2-5.9$ & Not identified & $\begin{array}{l}\text { Candida glabrata } \\
\text { (1 strain) }\end{array}$ \\
\hline Group 3 & 24 & $2.1-4.7$ & 1 & 4.3 & Not identified & $\begin{array}{l}\text { Pichia anomala } \\
\text { (1 strain) }\end{array}$ \\
\hline
\end{tabular}

\footnotetext{
${ }^{\text {a }}$ Moulds were inoculated on glutinous rice starch plates, incubated at $30{ }^{\circ} \mathrm{C}$ for $48 \mathrm{~h}$, and the plates were subsequently flooded with $0.25 \%$ iodine solution.

${ }^{\mathrm{b}}$ Fermentation tests were carried out on saccharified purple glutinous rice liquid, standardized at $20^{\circ}$ Brix, in conical flasks with water locks. Analysis was done after 5 days of incubation at $30^{\circ} \mathrm{C}$.
} 
order can produce alcohol under low oxygen conditions (Cronk, Steinkraus, Hackler, \& Mattick, 1977). Similary, the five randomly selected yeast isolates from group 1 that showed superior fermentation ability were identified and they all belonged to the species Saccharomyces cerevisiae. Although other yeasts such as Saccharomycopsis fibuligera (Knox, Preez, \& Kilian, 2004) have been identified in rice starters as well, it is not surprising to encounter $S$. cerevisiae, as numerous studies document that the species $S$. cerevisiae is predominant in alcoholic fermented beverages (Barnett et al., 2000; Battcock \& Ali, 1993). Besides, two representative isolates belonging to the other two groups that had the lower ethanol producing capacity were also included in the classification. They were identified as Candida glabrata and Pichia anomala. In fact, all these isolates originated from the six rice wine starters that had been selected for their superior ability to liquefy cooked rice, high ethanol accumulation, and attractive flavour and colour of the resulting wine. However, they performed very differently in starch degradation and ethanol production as well as belonged to different species. This is a consequence of the fact that original rice wine starters are not defined pure culture starters, but contain a mixed microflora. In further studies, the behaviour of high-performing strains as single or mixed pure cultures should be tested. The compatibility of moulds and yeasts is an important aspect for the production of starters with good quality. Therefore further research into the interaction of moulds and yeasts predominating in these starters will be required.

\section{Acknowledgements}

This research was financially supported by the Ministry of Foreign Affairs, The Hague, The Netherlands and the International Foundation for Science, Stockholm, Sweden (Grant No. E/3322-1). We would like to thank staff members of the Centraalbureau voor Schimmelcultures (CBS), Utrecht, the Netherlands, for their professional comments on the identification of moulds and yeasts. We also give many thanks to local producers of rice wine and fermentation starters for their enthusiastic cooperation.

\section{References}

Barnett, J. A., Payne, R. W., \& Yarrow, D. (2000). Yeasts-characteristics and identification (3rd ed.). Cambridge: Cambridge University press.

Basuki, T., Dahiya, D. S., Gacutan, Q., Jackson, H., Ko, S. D., Park, K. I., et al. (1996). Indigenous fermented foods in which ethanol is a major product. In K. H. Steinkraus (Ed.), Handbook of indigenous fermented foods (pp. 363-508). New York: Marcel Dekker.

Battcock, M., \& Ali, S. A. (1993). Fermented fruits and vegetables. FAO Agricultural Services Bulletin, 134, 13-28.

Cronk, T. C., Steinkraus, H., Hackler, L. R., \& Mattick, L. R. (1977). Indonesian Tape Ketan fermentation. Applied and Environmental Microbiology, 33(5), 1067-1073.

Han, B.-Z., Kuijpers, A. F. A., Thanh, N. V., \& Nout, M. J. R. (2004). Mucoraceous moulds involved in the commercial fermentation of Sufu Pehtze. Antonie van Leeuwenhoek, 85, 253-257.

Hesseltine, C. W. (1983). Microbiology of oriental fermented foods. Annual Review of Microbiology, 37, 575-601.

Hesseltine, C. W. (1991). Zygomyces in food fermentations. Mycologist, 5 , $152-169$.

Hesseltine, C. W., Rogers, R., \& Winarno, F. G. (1988). Microbiological studies on amylolytic oriental fermentation starters. Mycopathologia, 101, 141-155.

Knox, A. M., Preez, J. C., \& Kilian, S. G. (2004). Starch fermentaion characteristics of Saccharomyces cerevisiae strains transformed with amylase genes from Lipomyces kononenkoae and Saccharomycopsis fibuligera. Enzyme and Microbial Technology, 34, 453-460.

Kurtzman, C. P., Boekhout, T., Robert, V., Fell, J. W., \& Deak, T. (2003). Methods to identify yeasts. In T. Boekhout, \& V. Robert (Eds.), Yeasts in food: Beneficial and detrimental aspects (pp. 69-121). Hamburg: B. Behr's Verlag GmbH \& Co. KG.

Kurtzman, C. P., \& Fell, J. W. (1998). The yeasts, a taxonomic study (4th ed.). Amsterdam: Elsevier.

Lim, G. (1991). Indigenous fermented foods in South East Asia. ASEAN Food Journal, 6, 83-101.

Luong, N. D. (1998). Production of fermented drinks (in Vietnamese). In N. D. Luong (Ed.), Microbiological technology, Vol. 3 (pp. 175-188). HCM City, Vietnam: Technology University.

Middelhoven, W. J. (2000). Identification of yeasts present in sour fermented foods and fodders. In J. F. T. Spencer, \& A. L. Ragout de Spencer (Eds.), Methods in biotechnology - food microbiology protocols (pp. 209-224). Totowa: Humana Press Inc.

Nout, M. J. R., \& Aidoo, K. E. (2002). Asian fungal fermented food. In H. D. Osiewacz (Ed.), The mycota. Vol. X "industrial applications" (pp. 23-47). Berlin, Heidelberg, New York: Springer.

Phuc, N. H. (1998). The fermentation processes of traditional foods (in Vietnamese). HCM City, Vietnam: Agriculture Publisher.

Rohm, H., Lechner, F., \& Lehner, M. (1990). Evaluation of the API ATB $32 \mathrm{C}$ system for the rapid identification of foodborne yeasts. International Journal of Food Microbiology, 11, 215-224.

Samson, R. A., \& Hoekstra, E. S. (2002). Introduction to food- and airborne fungi (6th ed.). Utrecht: Centraalbureau voor Schimmelcultures.

Smith, M. T., Yarrow, D., \& Robert, V. (2002). Yeasts. In R. A. Samson, \& E. S. Hoekstra (Eds.), Introduction to food - and airborne fungi (6th ed., pp. 270-279). Utrecht: Centraalbureau voor Schimmelcultures.

Steinkraus, K. H. (1989). Industrialization of indigenous fermented foods. New York, Basel: Marcel Dekker, Inc.

Yarrow, D. (1998). Methods for the isolation, maintenance and identification of yeasts. In C. P. Kurtzman, \& J. W. Fell (Eds.), The yeasts, a taxonomic study (4th ed., pp. 77-100). Amsterdam: Elsevier. 